\title{
New horizons in treatment of osteoporosis
}

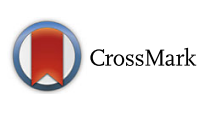

\author{
Ozra Tabatabaei-Malazy ${ }^{1,2}$, Pooneh Salari ${ }^{3}$, Patricia Khashayar ${ }^{4,5}$ and Bagher Larijani ${ }^{2 *}$
}

\begin{abstract}
Background: Prevalence of osteoporosis is increasing both in developed and developing countries. Due to rapid growth in the burden and cost of osteoporosis, worldwide, it seems reasonable to focus on the reduction of fractures as the main goal of treatment. Although, efficient pharmacological agents are available for the treatment of osteoporosis, there still remains a need to more specific drugs with less adverse effects.

Main body: This review article provides a brief update on the pathogenesis, presenting current pharmacological products approved by the US Food and Drug Administration (FDA) or Europe, and also newer therapeutic agents to treat osteoporosis according to the clinical trial data available at PubMed, UpToDate, International Osteoporosis Foundation (IOF), and clinical practice guidelines. As well, the effect of combination therapy and recommendations for future research will be further discussed.

Short conclusion: The use of current antiresorptive and anabolic agents alone or in combinations for the treatment of osteoporosis entails several limitations. Mainly, their efficacy on non-vertebral fracture reduction is lower than that observed on vertebral fracture. In addition, they have potential adverse events on long time usage. Development of newer agents such as cathepsin $\mathrm{k}$ inhibitor and strontium ranelate not only have increased the available options for treating osteoporosis, but also have opened doors of opportunity to improvements in the effective treatment. However, the high cost of new agents have restricted their usage in selective patients who are at high risk of fracture or whom failed response to first line treatment options. Thus, personalized medicine should be considered for future evaluation of genetic risk score and also for environmental exposure assessment. In addition to permanent attention to early diagnosis of osteoporosis and understanding of the pathophysiology of osteoporosis for novel approach in drug discovery, there seems a need to more well-designed clinical trials with larger sample sizes and longer duration on current as well as on newer agents. Also, continuous research on plant-derived components as the source of discovering new agents, and conducting more clinical trials with combination of two or more synthetic drugs, plants, or drug-plant for the treatment of osteoporosis are recommended.
\end{abstract}

Keywords: Osteoporosis, Treatment, Fractures, Antiresorptive, Anabolic agents, Personalized medicine, Plants

\section{Background}

Osteoporosis is one of the common health problems with a progressive prevalence both in developed and developing countries [1-3]. The definition of Osteoporosis based on World Health Organization (WHO) criteria is reduction in bone mineral density (BMD) of 2.5 standard deviations or more below that of the mean peak BMD of young adults when measured by dual-energy $\mathrm{x}$-ray absorptiometry (DEXA) [4]. This condition is influenced by different risk factors in terms of sex and age.

\footnotetext{
* Correspondence: Larijanib@tums.ac.ir

${ }^{2}$ Endocrinology and Metabolism Research Center, Endocrinology and Metabolism Clinical Sciences Institute, Tehran University of Medical Sciences, Fifth floor, Dr.Shariati Hospital, North Kargar Ave, Tehran 14114, Iran Full list of author information is available at the end of the article
}

In accordance with the recent estimation of International Osteoporosis Foundation (IOF) there are 200 million osteoporotic women in the world with an accident of osteoporotic fracture every 3 seconds [1]. Both primary and secondary types of osteoporosis are associated with reduction in bone mass and microarchitecture that result in bone fragility with a significant increase in disability, morbidity, and fracture risk [5]. Thus, access to diagnosis and adequate therapy for osteoporosis is a main challenge worldwide.

Osteoporosis is more prevalent in women than men; $34 \%$ versus $17 \%$, respectively. Usually, osteoporosis is prevalent in postmenopausal women and is presented as fractures in hip and spine due to accelerated bone turnover secondary to estrogen deficiency. However, vitamin 
D insufficiency and hyperparathyroidism remain as the main causes of osteoporosis in men and premenopausal women. By 2050, the worldwide incidence of hip fracture is expected to rise by $240 \%$ in women and $310 \%$ in men compared to 1990 involving approximately 1.66 million in 1990 to 6.26 million in 2050 [1]. Total cost for treating the prevalent osteoporotic-related fractures in the United States was estimated \$19 billion in 2005 that would be tripled by the year $2040[6,7]$. The annual hospitalization cost of osteoporotic fractures in US was shown to be equal or more than annual care costs associated with some chronic diseases such as myocardial infarction (MI), cerebrovascular accident, and breast cancer in 2011 [8].

A systematic review showed that the costs of osteoporosis treatment were not only greater than pre-fracture costs (as 1.6-6.2 times), but also were more than those spent for matched controls (2.2-3.5 times) [9].

Thus, due to the rapid growth in burden and cost of osteoporosis worldwide, it will be reasonable to focus on reduction of fractures as the main goal of treatment. WHO has developed an individual patient model known as $\mathrm{FRAX}^{\circ}$ to calculate individual fracture risk identifying patients at higher risk of fracture based on clinical risk factors and femoral neck BMD [10]. In addition to this, it is important to have a more accurate and comprehensive look on the pharmacologic therapies of the osteoporosis.

This review article provides an update on the most current pharmacological products approved by Europe or the US Food and Drug Administration (FDA) to treat osteoporosis according to available data at PubMed, UpToDate, IOF, and clinical practice guidelines.

\section{Pathogenesis}

Bone is composed of osteoblasts and osteocytes (boneforming cells), osteoclasts (bone-reabsorbing cells) and osteoid (bone matrix). When the balance between bone resorption and deposition tips toward excessive resorption, bone loss occurs as a forerunner of osteoporosis [11].

Osteoporosis is a multifactorial disease which has a complex pathophysiology potentially caused by genetic, endocrine disorders, and nutritional factors. Some hormones have been shown to be effective in bone development among which parathyroid hormone (PTH), calcitonin, estrogen and vitamin $\mathrm{D}$ are considered the most important ones [12]. PTH not only can increase production of the activated form of vitamin D $(1,25$ dihydroxyvitamin $\mathrm{D}$ or Calcidiol), but also can increase calcium absorption through kidneys, bone, and intestine. In addition, PTH can advance osteoclasts' activity that result in further bone resorption. Calcitonin plays roles in protection of calcium by direct and indirect inhibition of the PTH effects that result in reduction of calcium resorption from kidneys, calcium uptake from intestine, and suppression of bone resorption. Calcitonin reversibly blocks osteoclasts' function by binding to its receptor [12]. Estrogen reduces the rate of bone remodeling and increases osteoclast

apoptosis through two receptors including estrogen receptor $\alpha(E R \alpha)$ and estrogen receptor $\beta$ (ER $\beta)$. Estrogen deficiency has a critical role in the pathogenesis of osteoporosis due to its association with increased bone resorption, and impaired bone formation [13].

Bone micro-damages stimulate osteocytes to transmit resorption signals towards osteoclasts. In an immunological pathway, receptor activator of NF-KB (RANK) is expressed as pre-osteoclasts [14]. Function and differentiation of osteoclasts are regulated by RANK/RANK ligand (RANKL) interaction that can be blocked by osteoprotegerin (OPG) (Fig.1). PTH, PTH-related protein (PTHrP), cytokines, and prostaglandins can increase osteoclastogenesis by up-regulation of RANKL and down-regulation of OPG expression [12].

Bone remodeling requires the activities of both wingless-type and integrase 1 (Wnt) and bone morphogenetic protein (BMP) pathways to regulate osteoblast function (Fig.1). Critical role of Wnt signaling pathway, and absence of runt-related transcription factor 2 (Runx2) have been shown in regulating osteoblast differentiation and function. Wnt signaling is up-regulated by interaction of LDL receptor-related protein 5 (LRP5) and frizzled receptors (Frz), and is down-regulated by Dickkopf (DKK) as an inhibitor of LRP5 and secreted frizzled-related protein (SFRP) [13].

Sclerostin acts as an antagonist and blocks both BMP and Wnt signaling pathways, but canonical $\beta$-catenin performs as a synergism with BMP2 and Wnt. Thus, preventing mutations of gene encoding sclerostin (SOST) can increase bone formation and bone mass [8]. Some of other reasons associated with impaired bone formation are agerelated reduction in the capacity of osteoblasts to replicate and differentiate, local and systemic growth factors deficiencies (IGF-1, TGF- $\beta$ ), prostaglandins (PGE2), leukotrienes (arachidonate 15-lipoxygenase that encoded by Alox 15), and leptin deficiency or resistance [13-15]. An inverse relationship between adipocytes and osteoblasts in the bone marrow via PPARY has been shown as a master regulator of adipogenesis. Also, a close association not only between bone and insulin sensitivity, but also between osteoporosis and obesity or diabetes mellitus has been reported $[16,17]$.

The key role of oxidative stress, epigenetic, and gut microbiota in the pathogenesis of osteoporosis is established, too. Oxidative stress is an imbalance between the production of reactive oxygen species (ROS) and antioxidative defense. The effect of oxidative stress on bone is presented as reduction in bone mass, bone formation, osteoblast numbers and dysfunction of osteoblasts 


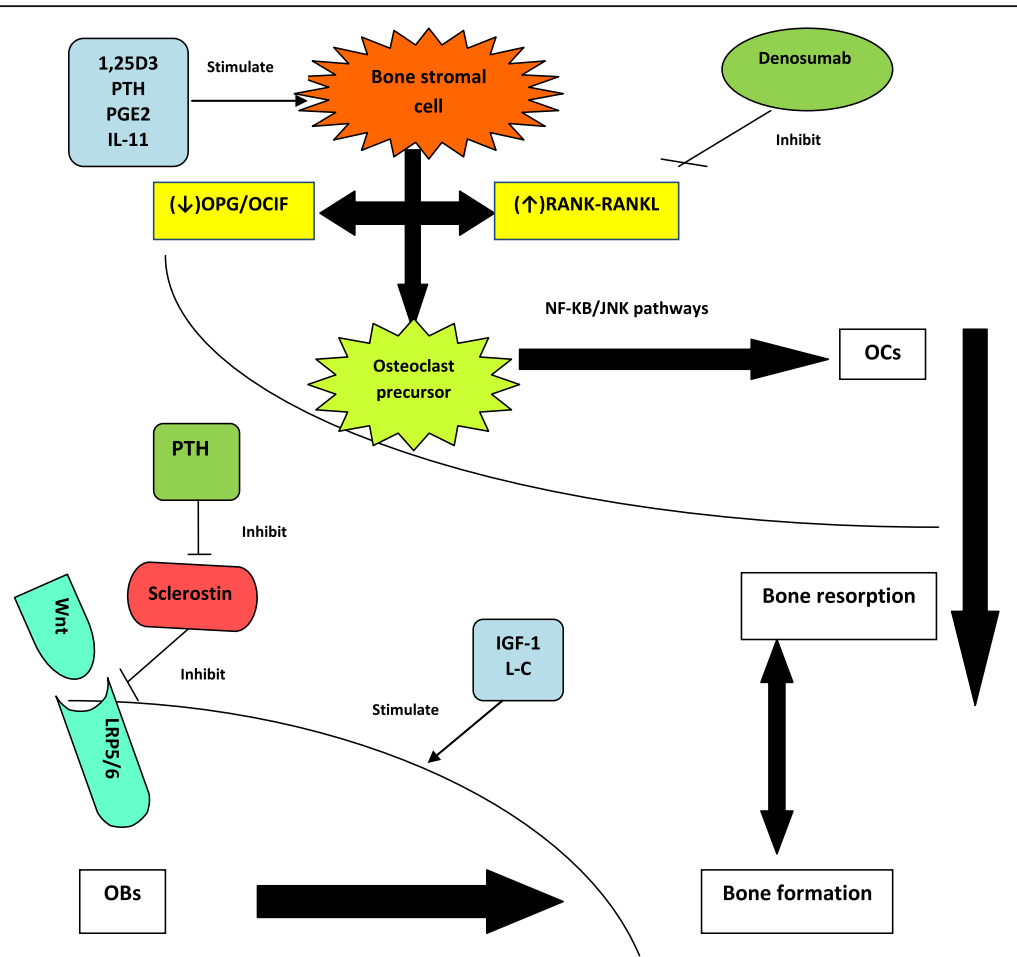

Fig. 1 A brief schematic view of pathophysiology of osteoporosis and influence of some drugs on bone health. Legend: PTH: parathyroid hormone; PGE2: prostaglandin E2; IL-11: interleukin-11; OPG: osteoprotegerin; OCIF: osteoclastogenesis inhibitory factor; RANKL: receptor activator of nuclear factor KB ligand; NF-KB: nuclear factor KB; JNK: C-Jun N-terminal kinases; OCs: osteoclasts; Wnt: wingless and Int proteins; LRP5/6: LDL-receptor related protein 5/6; IGF-1: Insulin like growth factor-1; L-C: L-carnitine; OBs: osteoblasts

[16-19]. Epigenetic is referred to a stable change of normal gene expression without altering DNA sequence in response to various environmental stimuli, different pharmacological agents, and nutrients. All three types of epigenetic markers including DNA methylation, posttranslational histone modification, and miRNA are influenced by regulation of gene expression in bone cells $[18,20]$. The effects of gut microbiota on bone cell have been mediated through immune systems. Gut microbiota can increase bone mass and density and can strengthen it by enhancing the synthesis and absorption of $\mathrm{Ca}$, magnesium, vitamins $\mathrm{K}$ and B12. Moreover, the synthesis of serotonin and availability of tryptophan as a serotonin precursor, as well as suppression of osteoclastogenesis is improved [21].

\section{Management of osteoporosis}

Pharmacological agents are used as the typical treatment of osteoporosis. However, lifestyle modifications through receiving adequate nutritional supplements (including calcium intake about $1200 \mathrm{mg}$ daily and vitamin D intake in range of 1000-2000 IU daily with higher amount in some patients), weight bearing activity at least $30 \mathrm{mi}$ nutes daily, avoiding or stopping smoking, avoiding heavy alcohol consumption to $\leq 2$ servings daily, limiting caffeine intake, and practical and emotional support by health providers, family and friends have important roles in maintaining bone health [22-24]. In addition, surgical treatments such as vertebroplasty and kyphoplasty have been used for pain relief. It is notable that the main adverse effect of osteoporosis is the increasing risk of vertebral fracture. Due to limitations in published studies assessing the role of these procedures for osteoporosis, their benefits have still remained uncertain [22, 23]. Summary of recommended lifestyle modifications and pharmacological agents for osteoporosis are shown in Table 1.

\section{Calcium and vitamin D supplementation}

In some countries calcitriol and alfa-calcidol have been used as synthetic analogues of vitamin D for the treatment of osteoporosis. A meta-analysis showed that vitamin D supplementation alone cannot reduce fracture risk. However, the results of another meta-analysis revealed a fracture risk reduction at vertebral and nonvertebral sites $[25,26]$. However, the beneficial effect of calcitriol was reported for prevention of bone loss in osteoporosis after glucocorticoid therapy or after transplantation of solid organ or stem cell [27]. The main adverse effects of vitamin $\mathrm{D}$ derivatives are increasing the serum and urine level of calcium. The beneficial 
Table 1 Summary of treatment modalities for osteoporosis

\begin{tabular}{lll}
\hline Treatment modalities & Drug class & Medications \\
\hline Lifestyle modifications & $\begin{array}{l}\text { Nutritional supplements } \\
\text { Physical activity } \\
\text { Smoking cessation } \\
\text { Limited alcohol \& caffeine } \\
\text { consumption }\end{array}$ & Calcium \& Vitamin D \\
Pharmacological agents (antiresorptive drugs) & BPs & \\
& RANKL antibody & Alendronate, Risedronate, Ibandronate, Zoledronic acid, \\
& Estrogen replacement & Clodronate, Minodronate, Pamidronate, Etidronate, Tiludronate \\
& SERMs & Denosumab \\
& Calcitonin & Estrogen conjugate \\
& Cathepsin k inhibitors & Raloxifene, Tamoxifene, Lasofoxifene, Bazedoxifene, Arzoxifene \\
& Strontium ranelate & Calcitonin \\
Pharmacological agents (anabolic drugs) & PTH peptides & Odanacatib, Balicatib, ONO-5334 \\
& Anti-sclerostin antibodies & Strontium \\
\hline
\end{tabular}

Legend: BPs Bisphosphonates, SERMs selective estrogen receptor modulator

effects of adequate intake of calcium (Ca) and vitamin D on rate of bone loss and fracture risk has been shown in a study [28]. Some of meta-analysis studies reported 0.81-0.87 relative risk reduction for hip fracture (13-19\% reduction) by combination of $\mathrm{Ca}$ with vitamin $\mathrm{D}[29$, 30]. Generally, recommended daily intake of $\mathrm{Ca}$ and vitamin $\mathrm{D}$ in postmenopausal osteoporotic women is $1200 \mathrm{mg}$ (total intake by diet and supplements) and 800 international units (IU), respectively. These amounts can change to $1000 \mathrm{mg}$ (total intake by diet and supplements) and $600 \mathrm{IU}$, respectively, in premenopausal osteoporotic women and men [31].

\section{Pharmacological agents for treatment of osteoporosis}

Pharmacological agents are classified into two groups, antiresorptive and anabolic agents. The main mechanism of action of antiresorptive agents is reduction of bone resorption through inhibiting the activity of osteoclasts. Drugs of this class include calcitonin, bisphosphonates, estrogen, selective estrogen-receptor modulators, and denosumab. Administration of anabolic agents can result in new bone formation through stimulating the function of osteoblasts.

These medications may have some beneficial effects on extra-skeleton tissues and organs but by considering the most part of the burden of osteoporosis which is related to fractures especially hip fracture; the current approach to treatment of osteoporosis is focused on patient's BMD and fracture risk. The beneficial effects of the pharmacological agents were presented in Table 2.

\section{Approved FDA/Europe antiresorptive drugs}

Bisphosphonates (BPs) BPs are recommended as the first-line medications for treatment of osteoporosis. Their effects on bone cells are most notable through inactivating osteoclastic bone resorption and accelerating apoptosis of osteoclasts. BPs can increase BMD, and decrease fracture risk. Drugs of this group include alendronate $\left(\right.$ Fosamax $\left.^{\circ}\right)$, risendronate $\left(\right.$ Actonel $\left.^{\circ}\right)$, ibandronate $\left(\right.$ Boniva $\left.^{\circ}\right)$, zoledronic acid (Reclast $\left.{ }^{\circ}\right)$, clodronate $\left(\right.$ Bonefos $^{\circ}$, Clasteon $\left.^{\circ}\right)$, minodronate $\left(\right.$ Onobis $\left.^{\circ}\right)$, pamidronate $\left(\right.$ Aredia $\left.{ }^{\circ}\right)$, etidronate $\left(\right.$ Didronel $\left.^{\circ}\right)$, and tiludronate $\left(S_{k e l i d}\right)^{\circ}$ which are different in terms of structure, potency, and affinity to bone. In addition, some of them such as etidronate and pamidronate are available in the US but not approved for prevention or treatment of osteoporosis [22].

Alendronate and risendronate are the most commonly used BPs worldwide. Alendronate not only has high affinity to bone, but also its effects have longer duration. Initiation of protective anti-fracture effect of alendronate is varied based on bone sites; 12,18 , or up to 24 months after treatment for vertebral bone, hip, and nonvertebral bone, respectively. Risendronate has a low affinity to bone, and its protective anti-fracture effect is started at least 6 months after treatment for vertebral and non-vertebral bones [32].

However, an increase in spine BMD rather than decrease in fracture risk was shown for zoledronic acid [33]. Clodronate is a weak BPs with beneficial effects on spine and hip BMD as well as vertebral and nonvertebral fracture risk in clinical trials. Its usage for osteoporosis has been approved in Europe [22]. A network meta-analysis compared the short term efficacy of different BPs including alendronate, clodronate, ibandronate, minodronate, pamidronate, risedronate, zoledronic acid, etidronate, and tiludronate in prevention of fractures in primary osteoporosis. The most effective BPs in the prevention of fracture at any sites was zoledronic acid, but alendronate or zoledronic acid 
Table 2 Summary of characteristics of pharmacological agents for treating osteoporosis in clinical trials' studies

\begin{tabular}{|c|c|c|c|c|c|}
\hline \multirow[t]{2}{*}{ Drugs class } & \multirow[t]{2}{*}{ Medication } & \multirow[t]{2}{*}{ Route of administration } & \multicolumn{2}{|l|}{ Evidences of main effect } & \multirow[t]{2}{*}{ Ref. } \\
\hline & & & Increase in BMD & Decrease in fracture risk & \\
\hline \multicolumn{6}{|c|}{ FDA/EU Approved } \\
\hline \multirow[t]{16}{*}{ Antiresorptive } & $B P S$ & & & & \\
\hline & Alendronate & $\mathrm{PO}$ & $\begin{array}{l}\text { Spine } 6.2 \% \text {, hip } 4.1 \% \text {, } \\
\text { LS 5.4\%, FN 1.6\%, }\end{array}$ & $\begin{array}{l}\text { Vertebral } 47 \% \text {, hip 51\%, } \\
\text { non-vertebral } 16 \%\end{array}$ & {$[1,33,37]$} \\
\hline & Risedronate & $\mathrm{PO}$ & Trochanter 3.3\% & $\begin{array}{l}\text { Vertebral 36\%, } \\
\text { non-vertebral } 27 \% \text {, } \\
\text { hip } 40 \%\end{array}$ & {$[1,37]$} \\
\hline & Ibandronate & $\mathrm{PO} / \mathrm{IV}$ & Nearly 6\% for LS \& hip & $\begin{array}{l}\text { Vertebral } 50 \%, \\
\text { Non-vertebral } 30-40 \%\end{array}$ & {$[1,22,34-37]$} \\
\hline & Zoledronic acid & IV & LS 3.2\%, FN 24\% & $\begin{array}{l}\text { Vertebral 70\%, } \\
\text { non-vertebral 25\% } \\
\text { (including hip 40\%) }\end{array}$ & {$[37,38]$} \\
\hline & Clodronate & $\mathrm{PO} / \mathrm{IM} / \mathrm{IV}$ & LS 3.7\%, hip 1.3\% & $\begin{array}{l}\text { Vertebral } 43 \% \text {, } \\
\text { non-vertebral 33\% }\end{array}$ & [22] \\
\hline & Denosumab & SC & LS 9.2-18.4\%, hip 4-8.3\% & $\begin{array}{l}\text { Vertebral } 68 \% \text {, hip 40\%, } \\
\text { non-vertebral } 20 \%\end{array}$ & {$[45,46]$} \\
\hline & $\begin{array}{l}\text { Estrogen Replacement } \\
\text { (ERT, HRT) }\end{array}$ & $\mathrm{PO}$ & LS 7.6\%, hip 4.5\% & $\begin{array}{l}\text { ERT: Vertebral 38\%, hip } \\
39 \% \\
\text { HRT: Vertebral 35\%, } \\
\text { hip 33\%, wrist 29\% }\end{array}$ & {$[22,52,53]$} \\
\hline & SERMS & & & & \\
\hline & Raloxifene & $\mathrm{PO}$ & LS 1.8\%, hip 2.1\% & $\begin{array}{l}\text { Vertebral } 35-43 \% \\
\text { non-vertebral } 10 \%\end{array}$ & {$[22,48,57]$} \\
\hline & Bazedoxifene & $\mathrm{PO}$ & $\begin{array}{l}\text { LS 2.2-2.7\%, hip } \\
(-1.15)-1.5 \%\end{array}$ & $\begin{array}{l}\text { (dose dependent) } \\
\text { Vertebral } 37-42 \% \text {, } \\
\text { non-vertebral no effect } \\
\text { to } 44-50 \% \text { reduction }\end{array}$ & {$[56,59,60]$} \\
\hline & $\begin{array}{l}\text { Bazedoxifene+ } \\
\text { conjugated estrogen }\end{array}$ & $\mathrm{PO}$ & LS 0.5-1.6\%, hip 0.5-1.5\% & NA & [62] \\
\hline & Tamoxifene & $\mathrm{PO}$ & LS $1.2 \%$ & $\begin{array}{l}\text { Overall } 32 \% \text { (hip } 32 \%, \\
\text { spine } 25 \% \text {, radius 31\%) }\end{array}$ & [63] \\
\hline & Lasofoxifene & $\mathrm{PO}$ & LS 1.8-3.0\%, hip 1.3-1.9\% & $\begin{array}{l}\text { (dose dependent) } \\
\text { Vertebral 31-42\%, } \\
\text { non-vertebral 22-24\%, } \\
\text { no effect on hip fracture }\end{array}$ & {$[64,66]$} \\
\hline & Arzoxifene & $\mathrm{PO}$ & LS $2.75-2.9 \%$, hip $1.53 \%$ & $\begin{array}{l}\text { Vertebral } 41 \% \text {, no reduced } \\
\text { non-vertebral }\end{array}$ & {$[67,68]$} \\
\hline & Calcitonin & Nasal spray/SC/IM & LS 1-1.5\% & Vertebral 60\% & [55] \\
\hline \multirow[t]{3}{*}{ Anabolic agents } & PTH peptides & & & & \\
\hline & Teriparatide & SC & Spine $8.6-13 \%$, FN 3.5-6\% & $\begin{array}{l}\text { Vertebral } 65-69 \% \\
\text { non-vertebral } 53 \%\end{array}$ & {$[6,55,72,73]$} \\
\hline & PTH 1-84 & SC & LS 6.9\%, FN 2.5\% & Vertebral 60\% & {$[11,73]$} \\
\hline
\end{tabular}

Newer Agents (awaiting FDA/EU approval)

Antiresorptive Cathepsin $k$ inhibitors

$\begin{array}{lll}\text { Odanacatib } & \text { PO } & \text { Spine } 11.9 \% \text {, total hip } 8.5 \%, \\ & & \text { FN } 9.8 \% \\ \text { ONO-5334 } & \text { Spine } 3.7-5.1 \% \text {, total hip 3\%, } \\ & & \text { FN 2.6\% } \\ \text { Strontium } & \text { PO } & \text { Dose dependent: LS 2.39-5.44\%, } \\ & \text { FN 2.52-8.25\%, total hip 1.02-8.25\% }\end{array}$

Hip 47\%, non-vertebral $23 \%$, clinical vertebral $72 \%$

NA

$[71,76]$

[78]

Vertebral $37-40 \%$,

non-vertebral

13\%, hip 5\% 
Table 2 Summary of characteristics of pharmacological agents for treating osteoporosis in clinical trials' studies (Continued)

\begin{tabular}{|c|c|c|c|c|c|}
\hline \multirow[t]{3}{*}{ Anabolic agents } & \multicolumn{5}{|l|}{$\begin{array}{l}\text { Anti-sclerostin } \\
\text { antibodies }\end{array}$} \\
\hline & Romosozumab & SC & $\begin{array}{l}\text { Dose dependent: LS 5.4-11.3\%, } \\
\text { total hip } 4.1 \% \text {, FN 3.7\% }\end{array}$ & NA & {$[84]$} \\
\hline & Blosozumab & SC/IV & $\begin{array}{l}\text { Dose dependent: spine } 8.4-17.0 \% \text {, } \\
\text { total hip } 2.1-6.3 \% \text {, FN 2.7-6.3\% }\end{array}$ & NA & [85] \\
\hline \multicolumn{6}{|c|}{ Combination therapy } \\
\hline \multirow{6}{*}{$\begin{array}{l}\text { Antiresorptive } \\
\text { and anabolic } \\
\text { agents }\end{array}$} & \multicolumn{5}{|l|}{$B P S+P T H$} \\
\hline & $\begin{array}{l}\text { Alendronate + } \\
\text { Teriparatide }\end{array}$ & $\mathrm{PO} / \mathrm{SC}$ & $\begin{array}{l}\text { LS } 14.8 \% \text { vs. } 18.1 \% \text { by PTH/ } \\
7.9 \% \text { by BPs, total hip without } \\
\text { differences }\end{array}$ & NA & [73] \\
\hline & $\begin{array}{l}\text { Risedronate }+ \\
\text { Teriparatide }\end{array}$ & $\mathrm{PO} / \mathrm{SC}$ & $\begin{array}{l}\text { Total hip } 3.9 \% \text { vs. } 0.3 \% \text { by PTH/ } 0.8 \% \\
\text { by BPs, FN } 8.4 \% \text { vs. } 3.9 \% \text { by PTH/ } \\
0.5 \% \text { by BPs }\end{array}$ & NA & {$[73,93]$} \\
\hline & $\begin{array}{l}\text { Zoledronic acid + } \\
\text { Teriparatide }\end{array}$ & IV/SC & $\begin{array}{l}\text { LS } 7.5 \% \text { vs. } 7.0 \% \text { by PTH/ } 4.4 \% \text { by BPs, } \\
\text { total hip } 2.3 \% \text { vs. } 1.1 \% \text { by PTH / } 2.2 \% \\
\text { by BPs }\end{array}$ & NA & [93] \\
\hline & $\begin{array}{l}\text { Denosumab + } \\
\text { Teriparatide }\end{array}$ & SC/SC & $\begin{array}{l}\text { LS } 9.1 \% \text { vs. } 6.2 \% \text { by PTH/ } 5.5 \% \text { by } \\
\text { denosumab, total hip } 4.9 \% \text { vs. } 0.7 \% \\
\text { by PTH/ } 2.5 \% \text { by denosumab, FN } 4.2 \% \\
\text { vs. } 0.8 \% \text { by PTH/ } 2.1 \% \text { by denosumab }\end{array}$ & NA & [94] \\
\hline & $\begin{array}{l}\text { SERMs+ Teriparatide } \\
\text { Raloxifene }+ \\
\text { Teriparatide }\end{array}$ & $\mathrm{PO} / \mathrm{SC}$ & $\begin{array}{l}\text { LS } 6.2 \% \text { vs. } 5.2 \% \text { by PTH, total hip } 2.3 \% \\
\text { vs. } 0.8 \% \text { by PTH, FN } 2.2 \% \text { vs. } 1.0 \% \\
\text { by PTH }\end{array}$ & NA & [57] \\
\hline \multirow[t]{5}{*}{ Antiresorptives } & \multicolumn{5}{|l|}{$B P S+H R T$} \\
\hline & $\begin{array}{l}\text { Etidronate + } \\
\text { Estrogen }\end{array}$ & $\mathrm{PO} / \mathrm{PO}$ & $\begin{array}{l}\text { LS } 10.4 \% \text { vs.7.0\% by HRT, hip } 7.0 \% \\
\text { vs. } 4.8 \% \text { by HRT }\end{array}$ & NA & {$[95]$} \\
\hline & $\begin{array}{l}\text { Alendronate + } \\
\text { HRT }\end{array}$ & $\mathrm{PO} / \mathrm{PO}$ & $\begin{array}{l}\text { LS } 10.1 \% \text { vs. } 4.0 \% \text { by HRT, FN } 4.0 \% \\
\text { vs. } 2.0 \% \text { by HRT }\end{array}$ & NA & {$[35,96]$} \\
\hline & $\begin{array}{l}\text { Risedronate + } \\
\text { HRT }\end{array}$ & $\mathrm{PO} / \mathrm{PO}$ & $\begin{array}{l}\text { LS } 5.2 \% \text { vs. } 4.6 \% \text { by HRT, FN } 2.7 \% \\
\text { vs. } 1.8 \% \text { by HRT }\end{array}$ & NA & {$[35]$} \\
\hline & $\begin{array}{l}\text { BPS + SERMS } \\
\text { Alendronate + } \\
\text { Raloxifene }\end{array}$ & $\mathrm{PO} / \mathrm{PO}$ & $\begin{array}{l}\text { LS } 5.3 \% \text { vs. } 4.3 \% \text { by BPs/ } 2.1 \% \text { by } \\
\text { raloxifene, FN } 3.7 \% \text { vs. } 2.7 \% \text { by BPs/ } \\
1.7 \% \text { by raloxifene, }\end{array}$ & NA & {$[57,95]$} \\
\hline
\end{tabular}

Legend: $B P s$ Bisphosphonates, FDA Food and Drug Administration, EU Europe, $P O$ oral route, $I V$ intravenous, SC subcutaneous, $I M$ intramuscular, $B M D$ bone mineral density, $L S$ lumbar spine, $F N$ femoral neck, Gl gastrointestinal, $H R T$ hormone replacement therapy, SERMs selective estrogen receptor modulators, $A F$ arterial fibrillation, NA no evidence available

revealed the highest effectiveness solely in preventing hip fracture [34]. Overall, the choice of BPs depends on the tolerance, cost, and medical history of patients. The influential effect of BPs in BMD and fracture risk varies in different studies. Some of the reasons are related to the age and sex of studied population, pre- or postmenopausal status, history of previous fracture, the type of the study (observational or clinical trial), and their comparison with placebo or other pharmacological treatments of osteoporosis [1, 22, 34-39]. A summary of the evidence-based data are shown in Table 2.

According to the American Association of Clinical Endocrinologists (AACE), response to treatment (not only with BPs but also with other pharmacological agents for treating osteoporosis) can be monitored by serial assessment of BMD (hip and lumbosacral) every one-two years after initiating BPs therapy until change in BMD become stable, and then repeats every two years or at less frequent intervals [23]. In some situations that absorption or efficacy of the drugs may be negatively affected, measuring bone turnover markers is recommended as an additional option; urinary N-telopeptide (NTX) and serum carboxy-terminal collagen crosslink (CTX) before and 3-6 months after initiating BPs and other antiresorptive agents. The extension of HORIZON-PFT trial and the Fracture Intervention Trial Long-Term Extension (FLEX) study revealed the highest beneficial effects of zelodronate after 3 years and alendronate after 5 years with regard to the fact that BMD and fracture outcomes were retained 6-9 years or 10 years after interrupting treatment with zelodronate or alendronate, respectively [40-42]. Thus, BPs therapy can be recommended beyond 5 years for patients at high risk of fracture. If the clinician decides to discontinue the treatment, it is necessary to assess BMD annually or biannually, concomitant to the measurement of bone 
markers and evaluating their changes. Hypocalcaemia, vitamin D deficiency, and renal dysfunction should be evaluated prior to initiating BPs through measuring serum level of $\mathrm{Ca}$, 25-hydroxyvitamin $\mathrm{D}$, and creatinine, and also the comorbidities that can influence on BPs usage and absorption should be assessed [35]. Some of these comorbidities are history of esophageal disorders such as achalasia that should be assessed before initiating oral BPs [35]. For achieving good efficacy of BPs, it is necessary to maintain optimal levels of calcium and vitamin $\mathrm{D}$ by adequate intake and/or supplementation. The most commonly reported adverse effects for oral BPs are gastrointestinal (GI) disturbances especially dyspepsia and esophagitis. So, oral BPs should be taken with an 8-ounce glass of water, upright for at least 30 minutes, and avoidance of sucking or chewing tablets. Flu-like symptoms was shown by taking large doses of oral or intravenous (IV) modes of BPs that can often be managed with acetaminophen. Other reported adverse effects are rare and include jaw osteonecrosis, atypical subtrochanteric femoral fractures, arterial fibrillation, and acute renal failure [35, 43-45]. Despite case reports of a serious adverse reaction by BPs [41], they have remained as the front line treatment for osteoporosis, at this time, based on risk-benefit ratio for using BPs especially reduction of the fracture risk $[23,35]$.

\section{Denosumab}

Denosumab (Prolia) is a human monoclonal RANKL antibody that results in osteoclast inactivation, apoptosis, and reduction in osteoclasts' differentiation by blocking the binding of RANKL to RANK. In addition a reduction of bone resorption as well as more than $80 \%$ decrease in serum level of CTX-1 has been reported [1]. Although it is not as the first-line pharmacological treatment of osteoporosis, but can be initiated as a first-line choice for treatment of osteoporosis in certain patients who are intolerant to oral BPs or have renal failure [46]. The "Fracture REduction Evaluation of Denosumab in Osteoporosis every 6 Months" (FREEDOM) trial showed the efficacy of denosumab on fracture-risk reduction at different skeletal sites among osteoporotic women [47]. Moreover, in patients at high fracture risk its beneficial effects were shown in older men under androgendeprivation therapy for prostate cancer, and women who receive adjuvant aromatase inhibitor for breast cancer. Generally, it is not recommended to be used in premenopausal women or children and for prevention of osteoporosis. Its combination with other pharmacological agents for osteoporosis is not suggested. Similar to BPs, hypocalcaemia and vitamin D deficiency should be managed before starting treatment, and adequate $\mathrm{Ca}$ and vitamin $\mathrm{D}$ should be administered during treatment with denosumab. It was reported that the beneficial effects of denosumab on bone initiate after one month and maintain at least 2 years in different clinical trials [23, 48, 49]. Monitoring of response to treatment with BMD is similar to monitoring of other pharmacological agents for osteoporosis that BMD evaluation is recommended 2 years after treatment. Due to the expression of RANK and RANKL on T lymphocytes, B cells, and dendrites' cells, an increase in the risk of infection by denosumab or its combination with other biologic agents is expected. Although there is no sufficient supportive data for infection or cancer in clinical trials, longitudinal studies are recommended to reveal the effect of longterm disruption in the receptor sites of RANK on immune system [48]. However, due to more frequent reports of serious infection and skin reaction with denosumab compared than placebo, patients should be informed to use appropriate drugs if develop signs of infection or skin reaction. Denosumab was not only well tolerated in osteoporosis clinical trials, but also no account of jaw osteonecrosis, arterial fibrillation, and symptomatic hypocalcaemia is reported, yet. Of the most commonly reported adverse effects were musculoskeletal pain, hypercholesterolemia, and cystitis [46].

\section{Estrogen replacement}

Due to the important role of estrogen deficiency on bone loss during menopause, it is suggested that use of estrogen replacement therapy (ERT) or estrogenprogestin (hormone) replacement therapy (HRT) alone is effective for prevention of osteoporosis in postmenopausal women [50]. Although the main effect of estrogen on bone health is reducing bone resorption, an anabolic effect was shown, too [51]. The Women's Health Initiative (WHI) and the Postmenopausal Estrogen/Progestin Intervention (PEPI) trial showed beneficial effects of either ERT or HRT at all skeletal sites concomitant with some adverse effects in long term usage [52-54]. Tibolone is an estrogen-progestin combination that is available outside of the US. It is formulated as tablet and is commercialized under different brand names around the world, for example as Boltin ${ }^{\circ}$ or Tibocina ${ }^{\circ}$ in Spain and Xyvion in Australia. Tibolone is used for prevention of osteoporosis and treatment of vasomotor symptoms of menopause. The Long-term Intervention on Fractures with Tibolone (LIFT) study conducted in postmenopausal women was shown its beneficial effects on reduction of fracture risk at vertebral $(45 \%)$ and at nonvertebral (26\%) sites [55]. It was shown that HRT can increase the risk of venous thromboembolic disorders, breast cancer, cardiac event and stroke, while ERT could enhance the risk of venous thromboembolic disorders, stroke, and endometrial cancer [23, 56]. Thus, estrogen replacement is recommended at the lowest effective dose and just for a short period. Moreover, HRT or ERT are 
not recommended as the first-line preventive treatment of osteoporosis. Beneficial effects of estrogen therapy on BMD will be decreased as nearly $5 \%$ during the first year after stopping treatment $[22,23]$.

\section{Selective estrogen receptor modulators (SERMs)}

Due to the adverse effects of estrogen in extra-skeletal organs, SERMs has been considered for treating osteoporosis in both sexes. SERMs contain nonsteroidal synthetic compounds with similar effects of estrogen on bone and cardiovascular system without any adverse effects of estrogen on breast and endometrium. This group includes raloxifene (Evsita ${ }^{\circ}$ ), tamoxifene (Solta$\left.\operatorname{mox}^{\circ}\right)$, lasofoxifene $\left(\right.$ Fablyn $\left.^{\circ}\right)$, and bazedoxifene (Viviant ${ }^{\circ}$, Conbriza ${ }^{\circ}$.

Raloxifene is the first produced drug of this class. Its beneficial effects on bone were shown in the Multiple Outcomes of Raloxifene Evaluation (MORE) trial and the Raloxifene Use for the Heart (RUTH) study as reduction in vertebral fracture risk without any significant effect on non-vertebral fracture risk [57-59]. The safety and efficacy of raloxifene on BMD can be extended for eight years according to clinical trials. Although some clinicians are continuing its usage after 8 years, no residual benefit was shown on BMD after stopping usage [57]. Due to reduction of BMD and enhancement of bone turnover associated with raloxifene in premenopausal women, it is not recommended in this population. Raloxifene can decrease the risk of breast cancer, but can increase the rates of stroke, thromboembolism, leg cramp, and postmenopausal vasomotor symptoms [49]. So, new drug discovery efforts should be focused on new versions of SERMs with maximum beneficial effects on bone and the least adverse effects.

Bazedoxifene that is available in Europe and Japan have similar effects to raloxifene in osteoporosis [60,61] but its long term safety or its impact on the risk of breast cancer is not yet determined. Although it is approved by Europe, is not approved yet by FDA at the time being. One formulation of bazedoxifene is its combination with conjugated estrogen (Duavee ${ }^{\circ}$ ) that can be used for treatment of osteoporosis and reduction of postmenopausal hot flashes [62]. Its common adverse effects are muscle cramps, GI disturbance, dizziness and neck pain. Other adverse effects are increased risk of stroke and thromboembolic diseases. Overall, the long term safety and preventive effect of Duavee on breast or ovarian cancers are unknown.

Tamoxifen as another drug from SERMs class has shown BMD reduction in premenopausal women by suppressing estrogen action on bone which is in contrast to its effect on postmenopausal women. But its impact on prevention or treatment of breast cancer in premenopausal is supportive. Thus, bone health can be monitored by evaluating BMD in this population $[57,63,64]$. Previous studies have reported that tamoxifen increases or stabilizes bone density, and decreases fracture rate in postmenopausal patients; however, no persisting benefit in terms of BMD is reported after 2 years of tamoxifen consumption following aromatase inhibitors treatment such as latrozole in postmenopausal women with estrogen receptor-positive breast cancer. Stopping tamoxifen would result in a rapid fall in estrogen levels induced by the aromatase inhibitors and may cause an accelerated BMD loss following the switch [65].

Due to the positive association between usage of tamoxifen and risk of endometrial hyperplasia or cancer, and vaginal bleeding, it should not be considered as the first-line therapeutic option of SERMs class for treating osteoporosis [57].

Lasofoxifene has shown protective effects on bone unlike its effect on breast and uterine. In different clinical studies conducted in postmenopausal osteoporotic women, some dose dependent beneficial and adverse effects of lasofoxifene at the dose of $0.25,0.5$, or $1.0 \mathrm{mg} /$ once daily were shown versus placebo [66, 67]. Lasofoxifene at the dose of $0.5 \mathrm{mg} /$ daily was associated with reduction in vertebral and non-vertebral fracture risk, estrogen positive breast cancer, cardiovascular diseases (CVD), stroke, and increasing risk of thromboembolic events compared with the dose of $0.25 \mathrm{mg} /$ daily [67]. It is approved by Europe but not approved by FDA.

Arzoxifene (LY353381) as a long acting raloxifene and ospemifene $\left(O p h e n a^{\circ}\right)$ that is structurally tamoxifenelike are new versions of SERMs with beneficial effects on bone such as increased BMD, decreased bone turnover, and fracture risk $[49,64,68]$. It should be noticed that clinical studies with ospemifene and arzoxifene are proceeding that are not approved by FDA, yet.

Generally, BPs or raloxifene are suggested as first-line choices for prevention of osteoporosis in postmenopausal women, pointing out that BPs are recommended over SERMs for treatment of osteoporosis. One should consider that the non-skeletal effects of SERMs have important role in selection of patients to use them. Raloxifene is contraindicated for prevention or treatment of osteoporosis in premenopausal women. BMD monitoring is required in the population taking tamoxifen [57].

\section{Calcitonin}

Calcitonin (Fortical ${ }^{\circ}$, Miacalcin ${ }^{\circ}$, Calcimar $^{\circ}$ ) as a natural 32-amino-acid peptide is secreted by C-cells of the thyroid. It is considered as a second-line therapy for osteoporosis in settings where first-line drugs have failed to response or patients are found intolerable. Calcitonin is administered in two dosage forms; injectable and nasal spray that bioavailability of nasal calcitonin is about $1 / 4$ that of its intramuscular route [69]. Usually, human calcitonin and salmon calcitonin have studied in clinical 
trials. Salmon calcitonin is used widely than human calcitonin due to its high affinity as 40 times more than human calcitonin for human calcitonin receptor. Calcitonin inhibits bone resorption through increasing osteoblast activity that results in reduction in vertebral fractures with a mild increase in spine BMD. Data on the effect of calcitonin on BMD of other skeletal sites are conflicting. However, its beneficial effects on bone were shown in both sexes by using both human and salmon calcitonin, both subcutaneous and intranasal routes $[11,69]$. There are not sufficient data on its effectiveness in women who are in the early postmenopausal years. Thus, it is recommended as a second-line treatment for women at more than 5 years after menopause. Due to some reasons, including lesser effectiveness of calcitonin than BPs, increased risk of cancer by its long-term usage, and less availability compared to BPs, calcitonin is typically not used for treating osteoporosis unless to relief acute pain (onset $<10$ days) secondary to osteoporotic fracture. In contrast, calcitonin is not effective for chronic pain (more than 3 months). The adverse effects include nausea, vomiting, flushing, allergic reactions, hypocalcaemia, nasal adverse reactions, calcitonin' antibodies formation, and prostate cancer. In required situations, one should cease its use in less than 6 months. In addition, after relieving from acute pain of fracture, calcitonin should be quickly switched to other pharmacological treatments of osteoporosis [69]. Calcitonin has withdrawn from the market in Europe and Canada. Although it is available in the US for treating osteoporosis, FDA Advisory Committee has not recommended it, yet [55]. In 2013, FDA advisory panels have recommended that marketing of calcitonin salmon for the treatment of osteoporosis in women greater than 5 years after menopause should be stopped. This is while in 2012, the European Medicines Agency had recommended that calcitonin salmon should not be used to treat osteoporosis after determining that the risk of developing cancer was $2.4 \%$ higher in patients using the nasal spray compared with in those who took placebo [70].

\section{Approved FDA/Europe anabolic agents}

PTH Teriparatide (recombinant human parathyroid 134) $\left(\right.$ Forteo $^{\circ}$ ) and intact molecule (amino acids 1-84) are peptides of $\mathrm{PTH}$ that have anabolic effects on bone mass and skeletal architecture by intermittent administration. Once daily subcutaneous administration of both agents have been shown to promote bone formation through activating osteoblasts' function by binding to PTH/ PTHrP type 1 receptor and stimulation of Wnt signaling pathway which resulted in increasing BMD and reducing fracture risk [71]. Both analogues can reduce vertebral fracture risk, but teriparatide can reduce non-vertebral fracture risk concomitant with reduced BMD in forearm
[72]. A meta-analysis study showed a reduction in the risk of back pain due to reduced occurrence of new painful vertebral fractures [73]. Abaloparatide (BA058 ${ }^{\circ}$ is a synthetic peptide analog of PTHrP that is in the process of applying to be approved in FDA and Europe. An increase by $6.7 \%$ was shown in a phase II clinical trial at lumbar spine BMD without significant difference from teriparatide and 2.6\% increase at total hip BMD by abaloparatide with a significant difference from teriparatide. A phase III clinical trial concluded the reduction of major osteoporotic fracture risk by applying both formulations but significantly marked the administration of abaloparatide [74]. The beneficial effect of abaloparatide was shown on wrist fracture, too. So, it seems that the abaloparatide is superior to teriparatide in terms of fracture prevention [74]. PTH analogous are not recommended as first-line drug given to the cost of $\mathrm{PTH}$ analogous, subcutaneous (SC) route of administration, and the availability of other pharmacological agents for treating osteoporosis [73]. On the other word, these drugs are suitable for patients at high risk of fracture, severe osteoporosis ( $\mathrm{BMD}<-3.0 \mathrm{~T}$ score), unsatisfactory response to anti-resorptive agents or unable to tolerate BPs, and patients with glucocorticoid-induced osteoporosis [6]. Its common adverse effects include dizziness, headache, nausea, and leg cramp [75]. Osteogenic sarcoma was shown followed by treatment with teriparatide in a dose and duration dependent pattern in experimental studies; however, it was not found in patients who used very trivial dosages of teriparatide [22]. Its use is contraindicated in patients with Paget, past bone irradiation therapy, hypercalcemia, hyperparathyroidism, bone metastasis, unexplained high level of alkaline phosphatase, and severe renal failure. It should be used with caution in patients with past or present history of kidney stones. Before the initiation of PTH therapy, BMD (if not assessed during two years ago), serum level of $\mathrm{Ca}$, phosphorus, creatinine, alkaline phosphatase, albumin, 25-hydroxy vitamin $\mathrm{D}$, and 24-hour urine excretion of $\mathrm{Ca}$ and creatinine should be evaluated. Vitamin D deficiency should be managed with vitamin D pretreatment. In addition, it is recommended to intake $1500 \mathrm{mg}$ daily $\mathrm{Ca}$ and 800 IU daily vitamin D while receiving PTH. Transient orthostatic hypotension was reported in some cases. Overall, teriparatide treatment is limited to 2 years in a patient's lifetime. Usually, monitoring of BMD is not recommended during the first to the second year of PTH therapy, but renal function and serum Ca measurements should be performed at least once during treatment with PTH [73]. The beneficial effect of PTH on fracture risk has persisted for at least 18 months (up to 30 months for teriparatide) after stopping treatment which can be avoided by taking an antiresorptive agent such as BPs [55]. 


\section{New agents}

The main goal of treating osteoporosis is based on marked increase in BMD and fracture free-period. Despite that current medications have effectively reduced fracture risk and increased BMD, understanding the targets of signaling pathways have helped to discovery of newer agents. Currently progression in development of newer agents such as cathepsin $\mathrm{k}$ inhibitor, strontium ranelate, AMG785, and AMG167 not only have increased the available options for treating osteoporosis, but also have opened doors of opportunity to improvements in the effective treatment.

\section{Cathepsin $k$ inhibitor}

Cathepsin $\mathrm{k}$ is a cysteine protease that is expressed by osteoclasts. Cathepsin k can degrade matrix proteins and type I collagen that results in bone resorption. Cathepsin $\mathrm{k}$ inhibitors such as odanacatib (MK-0822, MK-822), balicatib (AAE581), and ONO-5334 can reduce bone resorption, and bone formation. Beneficial effect of odanacatib in the interim analysis of a phase III clinical trial (The Long-term Odanacatib Fracture Trial, LOFT) with postmenopausal women has shown moderate reduction in bone resorption (50\%), lesser decrease in bone formation (30\%) concomitant with beneficial effect on hip and spine BMD. The beneficial effects of odanacatib as a selective cathepsin $\mathrm{k}$ inhibitor on BMD were reported to be dose dependent and persist up to 5 years by treatment. In addition, its fracture risk reduction effect is comparable with the effects of BPs and denosumab on similar bone sites [76]. Results of a number of phase II clinical trials have shown its beneficial effect on bone resorption markers in a dose dependent manner in both sexes $[77,78]$. A phase II clinical trial by AAE581 on site of ClinicalTrials.gov was found; however, the authors have not revealed any report of their study. Phase II OCEAN clinical trial demonstrated that ONO-5334 can decrease bone resorption similar to alendronate, with little or no change in bone formation and can increase BMD of lumbar spine, total hip and femoral neck comparable to alendronate [78]. However, its safety is not yet identified. All of these effects are reversible after stopping treatment. So, another medication should be added after taking off cathepsin $\mathrm{k}$ inhibitors to prevent loss of their beneficial effects on bone. Plaque-like skin thickening (morphea) that was one of the main adverse effects of early cathepsin $\mathrm{k}$ inhibitors (balicatib), was reported in $0.1 \%$ of users with odanacatib, ONO-5334 and other under development cathepsin $\mathrm{k}$ inhibitors (similar to placebo group). Some of the reported adverse effects of odanacatib versus placebo are trivial increase in the risk of stroke (1.4\% vs. $1.1 \%)$, arterial fibrillation $(1.1 \%$ vs. $1.0 \%)$, and atypical fractures $(0.1 \%$ vs. $0 \%)$. However, these types of drugs are still under development and await approval [71, 79].

\section{Strontium ranelate}

Strontium ranelate (Protelos ${ }^{\circ}$ ) is an antiresorptive agent approved in Europe for treatment of severe osteoporosis in mobile postmenopausal women at high risk of vertebral and hip fractures who cannot use or tolerate other pharmacological agents. In addition, it is recommended for use in Europe to treat osteoporosis in men at high risk of fracture. Although its mechanism of action is unclear, modest antiresorptive effect and little beneficial effect on bone formation are noted. Inhibition of osteoclasts' function as well as promotion of osteoblasts' activity through calcium sensing receptor (CaSR) by strontium resulted in increasing BMD and decreasing fracture risk [80-82]. In addition, its effects on osteoblast differentiation and proliferation have been shown. Since the replacement of $\mathrm{Ca}$ ions in the hydroxyapatite crystals by strontium salt leads to a larger apparent increase in BMD, one should consider to include correction factors in BMD data of the strontium users to make up the effects of this artifact which may influence DXA results. The magnitude of changes observed in BMD followed by strontium therapy is not suggestive of a greater reduction in fracture risk. On the other word, a greater BMD doesn't imply a larger reduction in fracture risk [27]. The more common reported adverse effects are cardiovascular events, venous thromboembolism, myocardial infarction, GI discomfort, and signs and symptoms of nervous system such as headache, seizure, memory loss, but rarely reported adverse effect is allergic reactions such as drug rash with eosinophilia and systemic symptoms (DRESS syndrome) [55, 77, 81]. Continuation of treatment with strontium should be stopped when hypertension, angina, or DRESS syndrome develop. In 2013, the European Medicines Agency's (EMA's) Committee for Medicinal Products for Human Use (CHMP) recommended a restriction in the use of the osteoporosis medicine Protelos/ Osseor (strontium ranelate), following an assessment of data showing an increased risk of serious heart attack, with no observed increase in mortality risk. The CHMP recommended that Protelos should only be used to treat severe osteoporosis in postmenopausal women or in men at high risk of fracture. Additional measures, including restrictions in patients with heart or circulatory problems, were also recommended to minimize the heart risks of the medicine [83].

\section{Anti-sclerostin antibodies}

Anti-sclerostin monoclonal humanized antibodies such as romosozumb (AMG785), blosozumab (AMG167), and BPS804 are osteocytes-derived Wnt signaling antagonists. Stress can stimulate osteoblasts to secret osteocytes as a mechanical signaling that results in decreasing the expression of sclerostin. On the other word, sclerostin prevents 
bone formation through suppressing the binding of LRP $5 / 6$ to Frz on osteoblasts which decrease differentiation, function and survival of osteoblasts. Increasing bone mass at spine and hips in clinical trials was shown concomitant with increasing in bone formation markers and decreasing in bone resorption markers by romosozumb and blosozumab $[84,85]$. Variations in both of these significant bone markers' will return to baseline levels (in a dose dependent manner) after 12 months which confirms the existence of other pathways independent of sclerostin for decreasing mechanical strain in the skeleton. Another reason of this event may be related to reduction of osteoblast progenitors or the compensatory activation of other signaling molecules such as DKK that reduce bone formation [86]. In addition, a positive association between bone mass and circulating level of sclerostin was shown in healthy men and women in contrast to the observed results in patients with bone disorders. The reason of this association may be related to high production of osteocytes as the main source of sclerostin secondary to higher bone mass [87]. So, more studies are needed to definite optimal doses, appropriate duration of treatment, and anti-fracture efficacy. The beneficial effects of anti-sclerostin antibodies were shown in animal models of other conditions resulted in decreasing BMD such as colitis, rheumatoid arthritis, osteoarthritis, osteogenesis imperfecta, and bone complications of type 2 diabetes mellitus [88]. The most frequently reported adverse effects are elevated liver enzymes after first dose that is normalized nearly after one month, and injection site reactions. There are rarely reported anti-blosozumab antibodies that decline with stopping treatment. In addition, just one case of nonspecific hepatitis after taking $10 \mathrm{mg} / \mathrm{kg}$ of romosozumab was reported which improved after 26 days [71]. By considering the hypothesis that activation of Wnt signaling can increase cardiovascular events or intracranial pressure due to unrestricted bone formation, and also the relation between sclerostin and some tumors such as colon cancer, long-term safety of these drugs are uncertain.

\section{Other therapies}

There are additional therapies for postmenopausal osteoporotic women such as vitamin $\mathrm{K}$, folic acid, vitamin B12 supplementations, androgens, and fluoride that are used in some countries, but are not recommended for routine use [27, 89]. However, there are other agents that have been shown to influence bone health through antiresorptive or anabolic mechanism, but are under investigations. The RGD sequence and human $\$ 3$ integrin have been reported as important targets for antiresorptive gene therapy. As a result, some studies have suggested the use of mesenchymal stem cells, which are osteoblast precursor cells, to carry the therapeutic gene. OPG, BMP and PTH have been reported as the most promising molecules for osteoporosis treatment, but not many new molecules have been studied as possible targets in this regard.

Various cytokines and cytokine antagonists (cDNA encoding the human interleukin-1 receptor antagonist (IL-1Ra) have also shown promising results as new therapeutic agents for osteoporosis in animal models, but their application is hindered by delivery problems. However, there are some barriers on use of these drugs for osteoporosis treatment that are as following $[90,91]$ :

- It was shown the calcified matrix of the bone tissue is considered as the main barrier in gene therapy for osteometabolic diseases, because the diffusion of the vector through such a matrix is practically impossible.

- Another obstacle in this regard is the use of single therapeutic genes in most studies, as a single gene cannot affect both the osteoblasts and the osteoclasts at the same time.

Overall, some of these new drugs are including frizzled-related protein inhibitor, glycogen synthase kinase 3 (GSK-3) inhibitors; lithium, 603281-31-8, 6bromoindirubin-3 -oxime, AR28, matrix metalloproteinases (MMPs), selective androgen receptor modulators (SARMs), cell adhesion molecules (CAMs), L-carnitine and its derivatives, amylin, adrenomedullin, reveromycin A, insulin like growth factor-1 (IGF-1), and mesenchymal stem cells $[18,49]$.

\section{Combination therapy}

It is hoped that the combination therapy show synergistic and additive anti-osteoporotic effects. So, combined agents with different mechanism of action such as antiresorptive plus anabolic agents or combination of two or more agents with the same mode of action such as inhibitors of bone resorption can be considered as an appropriate strategy for treatment of osteoporosis. However, it should be noticed that the metabolism of a drug is varied individually, and the safety and efficacy of drugs would change according to individual differences [92]. The combination of BPs and PTH 1-34 or PTH 1-84 in several clinical trials resulted in reduction in anabolic effect of PTH. In the most of studies alendronate in combination with PTH was used. Although combination therapy improved BMD at spine or hip, there was not additional benefit on BMD compared with PTH therapy alone [73]. The reduction of bone resorption markers was found in the studies conducted on both sexes showing no increase in bone formation markers in combination group. Recently, it was shown in one small clinical trial in osteoporotic men that the combination of teriparatide and risendronate increased BMD at hip compared 
with either therapy alone. Although BPs plus PTH is not recommended for management of osteoporosis, immediate use of BPs after withdrawing teriparatide can increase BMD at lumbosacral. Combinations of teriparatide and denosumab, estrogen or SERMs were shown small additive effect on BMD [73, 93, 94]. However, it should be noted that these studies were not designed to assess the effect of the combination on fracture risk.

Although some studies reported the combination of estrogen and BPs more effective than each of them alone, this combination is not recommended, because of the over suppression of bone turnover and enhancement of fracture risk $[95,96]$. Alendronate plus estrogen or raloxifene increased BMD to a greater extent when compared to either drug alone, in addition to unknown benefit for fracture reduction $[35,57]$. Overall, combination of the above drugs are not suggested because of their small beneficial effect on BMD, no proven additional benefit on fracture risk, increasing in cost and potential adverse effects of the drugs [93].

Combination of anti-inflammatory agents such as antitumor necrosis factor (anti-TNF) with anti-sclerostin antibodies in animal models have been shown to be more effective than either agent alone. By this combination was observed prevention of cortical and trabecular bone loss, and restoration of vertebral bone to levels in wild-type mice who had not arthritis. In addition, significant reduction of osteoclast number, suppression of bone erosion to lower level than baseline, and significant increase in thickness, area, and proteoglycan content of cartilage were observed [97]. Thus, it is suggested that medication selection would be on an individual basis. Personalized medicine that includes personalized genetic risk score and individualized environmental exposure may have a key role in pathophysiology of osteoporosis [98].

\section{Osteoporosis in men}

Due to the higher prevalence of osteoporosis among women than men, greater focus is paid on treatment of osteoporosis in women and several large randomized clinical trials have been conducted on this population. However, morality rate secondary to major fractures, especially of the hip, has increased in osteoporotic men than in women. Thus special attention should be paid to the treatment of osteoporosis in men. Similar approach is recommended in treating osteoporosis in both sexes. Osteoporotic men should intake adequate $\mathrm{Ca}$ (from 1000 to $1200 \mathrm{mg}$ daily according to age) and vitamin D (from 600 to 800 IU per day) supplementation in addition to pharmacological or hormonal therapy. Because the most common cause of osteoporosis in men is hypogonadism, testosterone replacement therapy can increase $\mathrm{BMD}$ by $5 \%$ in spine. Data of clinical trials confirms the beneficial effect of testosterone on BMD for at least 2 years [99]. Androgens have beneficial effects on cardiovascular system and adverse effects on prostate [100]. Androgen replacement therapy beside other pharmacological agents for treatment of osteoporosis is recommended for hypogonadal men at fracture risk [101]. Although it is expected that androgen therapy should have beneficial effects in elderly men with osteoporosis, sarcopenia, or falls, a meta-analysis study did not show its beneficial effects on bone health [102].

Overall, all pharmacological agents can be safely considered as a therapeutic option in the treatment of osteoporosis in men [103]. Alendronate or risendronate are favorable BPs that are recommended as the first line pharmacological therapy for osteoporosis in men. Zoledronic acid is a suitable alternative in patients who do not tolerate oral BPs. Denosumab is a good choice in osteoporotic men who are intolerant to other drugs or have renal failure. BPs therapy should be stopped in men with severe osteoporosis who are intolerant or unresponsive to BPs therapy after one year, and PTH therapy should be selected as an alternative. As recommended for postmenopausal women, monitoring of treatment with BMD evaluation is of utmost importance [101].

\section{Recommendations for future research}

It is not only required to conduct more studies on understanding the signaling pathway, but there are also needs to conduct more studies on prevention of osteoporosis, safety and efficacy of anti-osteoporotic pharmacological agents, and drug discovery. It was reported in most of the studies that antioxidative mechanism has the main role in prevention and treatment of osteoporosis [104-106]. Some of these products include green tea, quercetin, curcumin, phytoestrogens, omega-3 fatty acids and soy isoflavones. In addition, it was reported anti-resorptive effects for some active compounds such as flavonoids, terpenoids, glycosides, lignans, coumarins, alkaloids, and polyphenols, etc that have derived from medical plants [107-111].

Polyphenols that are found in the most plants has shown to be effective in increasing bone formation, decreasing bone resorption, and increasing bone strength. Epigallocatechin-3-gallate (EGCG) is the main polyphenol in green tea. Some of its beneficial effects on bone health are modulated through suppression of the transcription factors such as Runx2, or act through some molecular signaling pathways such as OPG/RANKL, mitogen-activated protein kinase (MAPK), and BMP that resulted in suppression of osteoclast differentiation, and affect osteoblast function [18]. Phytoestrogens can inhibit aromatase and cytochrome $\mathrm{P} 450$ by binding to estrogen receptors. High level of aromatase has positive association with risk of breast, adrenal and prostate cancers. Other mechanisms include the influence on 
calcium absorption and its urinary excretion, prostaglandin synthesis, osteoblast formation and lipid oxidation. The beneficial effect of phytoestrogens on bone resorption markers, and BMD in postmenopausal women in some meta-analysis of randomized controlled trials was reported, in contrast to others [112-115]. The effect of isoflavones on fracture risk was not seen. However, it should be noticed that phytoestrogens can be considered as the best alternative of estrogen therapy for relief of menopausal symptoms. Similar to synthetic drugs, it is hypothesized that more beneficial effects for polyherbal combination be revealed in the near future. The greens $+{ }^{\mathrm{TM}}$ a blend of several polyphenols including quercetin, apigenin and luteolin, combination of several types of omega-3 fatty acids, and Resveratrol in combination with vitamin $\mathrm{D}$ have shown beneficial effects on bone more than when used alone $[18,110,116]$. However, most of these studies have been performed in vitro and needs preclinical animal studies to optimize the dose with maximum beneficial effects on bone health, and then well-designed clinical studies with large sample sizes and long follow-up duration in at-risk populations.

\section{Conclusions}

Currently, the development of pharmacological agents in treatment of osteoporosis has discovered new agents that effectively reduce fracture risk. Due to the lack of appropriate clinical trials for newer anabolic or antiresorptive agents, until these agents are approved, it is recommended to prescribe the current available agents that is more appropriate to each patient. Thus, the physicians should be aware about the current drugs and also newer agents' mechanism of action, their beneficial effects on bone health, the best time to prevent fractures, optimal beneficial duration of treatment, and dosing requirement.

Some limitations exist despite the major advances in drug discovery for treatment of osteoporosis. First, their efficacy on hip fracture reduction is lower than what observed on lumbosacral fracture. Secondly, potential adverse events may emerge by using anti-osteoporotic pharmacological agents in postmenopausal osteoporotic women who need long term treatment. Thirdly; the benefits associated with so called treatment strategies are limited to selected patients, generally those at higher risk of fracture. However, monitoring of complications in long-term may raise some concerns. Forth, due to the high cost of new agents, their usage should be restricted in selective patients who are at high risk of fracture or when failed response to first line treatment options. In addition, individuality in the metabolism of a drug affects drug safety and efficacy. On the other hand, the progressive advances in the personalized therapy for osteoporosis raises the necessity for identifying the main genes and signaling pathways involved in bone loss of individual patients. Henceforth, the effects of these genes and pathways modulate the application of therapies in every specific individual. Thus, personalized medicine should be considered for genetic risk score and also for environmental exposure assessment.

In addition to continuous attention to the early diagnosis of osteoporosis, more well-designed clinical trials is required on the safety and efficacy of current available anti-osteoporosis agents. As well, continuous preclinical assessment of newer agents, conduction of clinical trials, searching for novel approach in drug discovery based on understanding of the pathophysiology of osteoporosis are strictly recommend. The authors also suggest conducting future research on plant-derived components as the source of discovery of new agents, and also more clinical trials with combination of two or more synthetic drugs, plants, or drug-plant for treatment of osteoporosis as the solutions.

\section{Abbreviations}

AACE: American Association of Clinical Endocrinologists; anti-TNF: anti-tumor necrosis factor; BMD: bone mineral density; BMP: bone morphogenetic protein; BPs: Bisphosphonates; Ca: calcium; CAMs: cell adhesion molecules; CaSR: calcium sensing receptor; CHMP: Committee for Medicinal Products for Human use; CTX: carboxy-terminal collagen crosslink; DEXA: dual-energy x-ray absorptiometry; DKK: Dickkopf; DRESS syndrome: drug rash with eosinophilia and systemic symptoms; EGCG: Epigallocatechin-3-gallate; EMA's: European Medicines Agency's; ERT: estrogen replacement therapy; ERa: estrogen receptor $\alpha$; ER $\beta$ : estrogen receptor $\beta$; FDA: Food and Drug Administration; FLEX: Fracture Intervention Trial Long-Term Extension; FREEDOM: Fracture REduction Evaluation of Denosumab in Osteoporosis every 6 Months; Frz: frizzled receptors; Gl: gastrointestinal; GSK-3: glycogen synthase kinase-3; HRT: estrogen-progestin replacement therapy;

IGF-1: insulin like growth factor-1; IOF: International Osteoporosis Foundation; IU: international units; IV: intravenous; LIFT: Long-term Intervention on Fractures with Tibolone; LOFT: Long-term Odanacatib Fracture Trial; LRP5: LDL receptor-related protein5; MAPK: mitogen-activated protein kinase; MMPs: matrix metalloproteinases; MORE: Multiple Outcomes of Raloxifene Evaluation; NTX: N-telopeptide; PEPI: Postmenopausal Estrogen/Progestin Intervention; PTHrP: PTH-related protein; RANK: receptor activator of NF-KB; RANKL: RANK ligand; ROS: reactive oxygen species; Runx2: runt-related transcription factor2; RUTH: Raloxifene Use for the Heart; SARMs: selective androgen receptor modulators; SERMs: Selective estrogen receptor modulators; SFRP: secreted frizzled-related protein; WHI: Women's Health Initiative; Wnt: wingless-type and integrase1

\section{Acknowledgements \\ This manuscript is at home working, without any financial support.}

\section{Funding}

This study is performed without any supporting fund.

\section{Availability of data and materials}

As this study was a desk research which did not included any human subjects (neither human data nor human material), this section is not applicable.

\section{Authors' contributions}

"OTM participated in the design of the study, collected data, and wrote draft of the manuscript. PS and PKH helped to collect data and co-operated in writing of the manuscript. BL conceived of the study, participated in its design, and helped to collect data. All authors read and approved the final manuscript."

\section{Competing interests}

The authors declare that they have no competing interests. 


\section{Consent for publication}

Not applicable.

\section{Ethics approval and consent to participate}

Not applicable.

\section{Author details}

'Diabetes Research Center, Endocrinology and Metabolism Clinical Sciences Institute, Tehran University of Medical Sciences, Tehran, Iran. ${ }^{2}$ Endocrinology and Metabolism Research Center, Endocrinology and Metabolism Clinical Sciences Institute, Tehran University of Medical Sciences, Fifth floor, Dr.Shariati Hospital, North Kargar Ave, Tehran 14114, Iran. ${ }^{3}$ Medical Ethics and History of Medicine Research Center, Tehran University of Medical Sciences, Tehran, Iran. ${ }^{4}$ Osteoporosis Research Center, Endocrinology and Metabolism Clinical Sciences Institute, Tehran University of Medical Sciences, Tehran, Iran. ${ }^{5}$ Center for Microsystems Technology, Imec and Ghent University, Gent-Zwijnaarde, Belgium.

Received: 18 November 2016 Accepted: 31 January 2017 Published online: 07 February 2017

\section{References}

1. Facts and statistics, osteoporosis general. Available at: https://www. iofbonehealth.org/facts-statistic\#category-14. Accessed 4 Feb 2017.

2. Larijani B, Moayyeri A, Keshtkar AA, Hossein-Nezhad A, Soltani A, Bahrami A, et al. Peak bone mass of Iranian population: the Iranian Multicenter Osteoporosis Study. J Clin Densitom. 2006;9:367-74.

3. Maalouf G, Gannage-Yared MH, Ezzedine J, Larijani B, Badawi S, Rached A, et al. Middle East and North Africa consensus on osteoporosis. J Musculoskelet Neuronal Interact. 2007;7:131-43.

4. World Health Organization: WHO scientific group on the assessment of osteoporosis at the primary health care level. Summary Meeting Report; Brussels, Belgium. 5-7 May 2004; World Health Organization; 2007.

5. Larijani B, Mohajeri Tehrani MR, Hamidi Z, Soltani A, Pajouhi M. Osteoporosis, global and Iranian aspects. Iranian Journal of Public Health. 2004;0(0):1-17.

6. Schuiling KD, Robinia K. Osteoporosis update. J Midwifery Womens Health. 2011;56:615-27. doi:10.1111/j.1542-2011.2011.00135.x.

7. Burge R, Dawson-Hughes B, Solomon DH, Wong JB, King A, Tosteson A. Incidence and economic burden of osteoporosis-related fractures in the United States, 2005-2025. J Bone Miner Res. 2007;22:465-75. doi:10.1359/JBMR.061113.

8. Singer A, Exuzides A, Spangler L, O'Malley C, Colby C, Johnston K, et al. Burden of illness for osteoporotic fractures compared with other serious diseases among postmenopausal women in the United States. Mayo Clin Proc. 2015;90:53-62. doi:10.1016/j.mayocp.2014.09.011.

9. Budhia S, Mikyas Y, Tang M, Badamgarav E. Osteoporotic fractures a systematic review of US healthcare costs and resource utilization. Pharmacoeconomics. 2012:30:147-70. doi:10.2165/11596880-000000000-00000.

10. Kanis JA, Hans D, Cooper C, Baim S, Bilezikian JP, Binkley N, et al. Task Force of the FRAX Initiative. Interpretation and use of FRAX in clinical practice. Osteoporos Int. 2011;22:2395-411. doi:10.1007/s00198-011-1713-z.

11. Introduction to bone biology. all about our bones. Available at: https:// www.iofbonehealth.org. Accessed 4 Feb 2017.

12. Crockett JC, Rogers MJ, Coxon FP, Hocking $\amalg$, Helfrich MH. Bone remodeling at a glance. J Cell Sci. 2011;124(Pt 7):991-8. doi:10.1242/jcs.063032.

13. Raisz LG. Pathogenesis of osteoporosis: concepts, conflicts, and prospects. J Clin Invest. 2005;115:3318-25. doi:10.1172/JCl27071.

14. Roodman GD. Mechanisms of bone metastasis. N Engl J Med. 2004;350:1655-64.

15. Nabipour I, Larijani B, Beigi S, Jafari SM, Amiri M, Assadi M, et al. Relationship among insulin like growth factor I concentrations, bone mineral density, and biochemical markers of bone turnover in postmenopausal women: a population-based study. Menopause. 2008;15:934-9. doi:10.1097/gme. Ob013e31816665a7.

16. Heshmat R, Tabatabaei-Malazy O, Abbaszadeh-Ahranjani S, Shahbazi S, Khooshehchin G, Bandarian F, et al. Effect of vitamin D on insulin resistance and anthropometric parameters in Type 2 diabetes; a randomized doubleblind clinical trial. Daru. 2012;20:10. doi:10.1186/2008-2231-20-10.

17. DePaula FJA, Rosen CJ. Obesity, diabetes mellitus and last but not least, osteoporosis. Arq Bras Endocrinol Metab. 2010;54:150-7.

18. Tabatabaei-Malazy O, Larijani B, Abdollahi M. Targeting metabolic disorders by natural products. J Diabetes Metab Disord. 2015;14:57. doi:10.1186/ s40200-015-0184-8.
19. Yousefzadeh G, Larijani B, Mohammadirad A, Heshmat R, Dehghan G, Rahimi $R$, et al. Determination of oxidative stress status and concentration of TGF- $\beta 1$ in the blood and saliva of osteoporotic subjects. Ann N Y Acad Sci. 2006:1091:142-50. doi:10.1196/annals.1378.062.

20. Vrtacnik P, Marc J, Ostanek B. Epigenetic mechanisms in bone. Clin Chem Lab Med. 2014;52:589608.

21. Ejtahed HS, Soroush AR, Angoorani P, Larijani B, Hasani-Ranjbar S. Gut microbiota as a target in the pathogenesis of metabolic disorders: a new approach to novel therapeutic agents. Horm Metab Res. 2016;48:349-58. doi:10.1055/s-0042-107792

22. Kanis JA, McCloskey EV, Johansson H, Cooper C, Rizzoli R, Reginster JY. Scientific Advisory Board of the European Society for Clinical and Economic Aspects of Osteoporosis and Osteoarthritis (ESCEO) and the Committee of Scientific Advisors of the International Osteoporosis Foundation (IOF). European guidance for the diagnosis and management of osteoporosis in postmenopausal women. Osteoporos Int. 2013;24:23-57. doi:10.1007/ s00198-012-2074-y.

23. Watts NB, Bilezikian JP, Camacho PM, Greenspan SL, Harris ST, Hodgson SF, AACE osteoporosis Tack Force, et al. American Association of Clinical Endocrinologists Medical Guidelines for Clinical Practice for the diagnosis and treatment of postmenopausal osteoporosis. Endocr Pract. 2010;16 Suppl 3:1-37.

24. Jeremiah MP, Unwin BK, Greenawald MH, Casiano VE. Diagnosis and management of osteoporosis. Am Fam Physician. 2015;92:261-8.

25. Richy F, Ethgen O, Bruyere O, Reginster JY. Efficacy of alphacalcidol and calcitriol in primary and corticosteroid-induced osteoporosis: a meta-analysis of their effects on bone mineral density and fracture rate. Osteoporos Int. 2004;15:301-10.

26. Richy F, Schacht E, Bruyere O, Ethgen O, Gourlay M, Reginster JY. Vitamin D analogs versus native vitamin $\mathrm{D}$ in preventing bone loss and osteoporosisrelated fractures: a comparative meta-analysis. Calcif Tissue Int. 2005;76:176-86.

27. Rosen HN, Drezner MK, Rosen CJ, Schmader KE, Mulder JE. Overview of the management of osteoporosis in postmenopausal women. Available at: www.uptodate.com. Accessed 4 Feb 2017.

28. Rahnavard Z, Eybpoosh S, Homami MR, Meybodi HA, Azemati B, Heshmat R, et al. Vitamin d deficiency in healthy male population: results of the Iranian multi-center osteoporosis study. Iran J Public Health. 2010;39:45-52.

29. Tang BM, Eslick GD, Nowson, Smith C, Bensoussan A. Use of calcium or calcium in combination with vitamin D supplementation to prevent fractures and bone loss in people aged 50 years and older: a meta-analysis. Lancet. 2007:370:657-66.

30. Avenell A, Mak JC, ÓConnell D. Vitamin D and vitamin D analogues for preventing fractures in post-menopausal women and older men. Cochrane Database Syst Rev. 2014;4, CD000227. doi:10.1002/14651858.CD000227.pub4.

31. Rosen HN, Rosen CJ, Schmader KE, Mulder JE. Calcium and vitamin D supplementation in osteoporosis. Available at: www.uptodate.com. Accessed 4 Feb 2017.

32. Simon JA. Are all bisphosphonates the same? Potential reasons for clinical differences: a perspective. J Womens Health. 2010;19:719-27.

33. Miller PD. All bisphosphonates are (or may not be) the same: potential reasons for clinical differences. J Womens Health. 2010;19:665-9.

34. Zhou J, Ma X, Wang T, Zhai S. Comparative efficacy of bisphosphonates in short-term fracture prevention for primary osteoporosis: a systematic review with network meta-analyses. Osteoporos Int. 2016 jun 7. [Epub ahead of print]

35. Rosen HN, Rosen CJ, Schmader KE, Mulder JE. The use of bisphosphonates in postmenopausal women with osteoporosis. Available at: www.uptodate. com. Accessed 4 Feb 2017

36. Harris ST, Blumentals WA, Miller PD. Ibandronate and the risk of nonvertebral and clinical fractures in women with postmenopausal osteoporosis: results of a meta-analysis of phase III studies. Curr Med Res Opin. 2008;24:237-45.

37. Wells GA, Cranney A, Peterson J, Boucher M, Shea B, Robinson V, et al. Alendronate for the primary and secondary prevention of osteoporotic fractures in postmenopausal women. Cochrane Database Syst Rev. 2008;1, CD001155. doi:10.1002/14651858.CD001155.pub2.

38. Cranney A, Wells GA, Yetisir E, Adami S, Cooper C, Delmas PD, et al. Ibandronate for the prevention of nonvertebral fractures: a pooled analysis of individual patient data. Osteoporos Int. 2009;20:291-7.

39. Black DM, Delmas PD, Eastell R, Reid IR, Boonen S, Cauley JA, et al. Onceyearly zoledronic acid for treatment of postmenopausal osteoporosis. $\mathrm{N}$ Engl J Med. 2007;356:1809-22. 
40. Black DM, Reid IR, Boonen S, Bucci-Rechtweg C, Cauley JA, Cosman F, et al. the effect of 3 versus 6 years of zoledronic acid treatment of osteoporosis: a randomized extension to the HORIZON-Pivotal Fracture Trial (PFT). J Bone Miner Res. 2012; 27: 243-54. doi: 10.1002/jbmr.1494.

41. Black DM, Schwartz AV, Ensrud KE, Cauley JA, Levis S, Quandt SA, et al. FLEX Research Group. Effects of continuing or stopping alendronate after 5 years of treatment: the Fracture Intervention Trial Long-term Extension (FLEX): a randomized tria. JAMA. 2006;296:2927-38.

42. Black DM, Reid IR, Cauley JA, Cosman F, Leung PC, Lakatos P, et al. The effect of 6 versus 9 years of zoledronic acid treatment in osteoporosis: a randomized second extension to the HORIZON-Pivotal Fracture Trial (PFT). J Bone Miner Res. 2015;30:934-44. doi:10.1002/jbmr.2442.

43. Aynardi M, llyas AF. Pharmacologic management of osteoporosis. J Hnad Surg Am. 2013;38:588-92. doi:10.1016/j.jhsa.2012.11.023.

44. Reid IR. Osteoporosis treatment: focus on safety. Eur J Intern Med. 2013;24:691-7. doi:10.1016/j.ejim.2013.03.012.

45. Salari $\mathrm{P}, \mathrm{Abdollahi} \mathrm{M}$. Long term bisphosphonate use in osteoporotic patients; a step forward, two steps back. J Pharm Pharmaceut Sci. 2012;15:305-17.

46. Rosen HN, Rosen CJ, Mulder JE. Denosumab for osteoporosis. Available at: www.uptodate.com. Accessed 4 Feb 2017.

47. Reginster JY, Neuprez A, Dardenne N, Beaudart C, Emonts P, Bruyere O. Efficacy and safety of currently marketed antiosteoporosis medications. Best Pract Res Clin Endocrinol Metab. 2014;28:809-34. doi:10.1016/j.beem.2014. 09.003.

48. Lim SY, Bolster MB. Current approaches to osteoporosis treatment. Curr Opin Rheumatol. 2015;27:216-24.

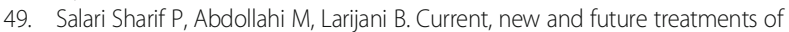
osteoporosis. Rheumatol Int. 2011;31:289-300. doi:10.1007/s00296-010-1586-Z.

50. Lindsay R, Hart DM, Forrest C, Baird C. Prevention of spinal osteoporosis in oophorectomised women. Lancet. 1980;2(8205):1151-4

51. Gennari L, Rotatori S, Bianciardi S, Gonnelli S, Nuti R, Merlotti D. Appropriate models for novel osteoporosis drug discovery and future perspectives. Expert Opin Drug Discov. 2015:10:1201-16. doi:10.1517/17460441.2015. 1080685.

52. Cauley JA, Robbins J, Chen Z, Cummings SR, Jackson RD, LaCroix AZ, et al. Women's Health Initiative Investigators Effects of estrogen plus progestin on risk of fracture and bone mineral density: the Women's Health Initiative randomized trial. JAMA. 2003;290:1729-38.

53. The Writing Group for the PEPI. Effects of hormone therapy on bone mineral density: results from the postmenopausal estrogen/progestin interventions 9PEPI) trial. JAMA. 1996;276:1389-96.

54. Martin KA, Barbieri RL, Synder PJ, Crowley WF. Menopausal hormone therapy: Benefits and risks. Available at: www.uptodate.com. Accessed 4 Feb 2017.

55. Komm BS, Morgenstern D, Yamamoto LA, Jenkins SN. The safety and tolerability profile of therapies for the prevention and treatment of osteoporosis in postmenopausal women. Expert Rev Clin Pharmacol. 2015;8: 769-84. doi:10.1586/17512433.2015.1099432.

56. Writing Group for the Women's Health Initiative Investigators. Risks and benefits of estrogen plus progestin in healthy postmenopausal women: principle results from the Women's Health Initiative randomized controlled trial. JAMA. 2002;288:321-33.

57. Rosen HN, Rosen CJ, Mulder JE. Selective estrogen receptor modulators for prevention and treatment of osteoporosis. Available at: www.uptodate.com. Accessed 4 Feb 2017.

58. Delmas PD, Ensrud KE, Adachi JD, Harper KD, Sarkar S, Gennari C, et al. Efficacy of raloxifene on vertebral fracture risk reduction in postmenopausal women with osteoporosis: four-year results from a randomized clinical trial. J Clin Endocrinol Metab. 2002;87:3609-17.

59. Barrett-Connor E, Mosca L, Collins P, Geiger MJ, Grady D, Kornitzer M, et al. Effects of raloxifene on cardiovascular events and breast cancer in postmenopausal women. N Eng J Med. 2006;355:125-37.

60. Silverman SL, Christiansen C, Genant HK, Vukicevic S, Zanchetta JR, de Villiers TJ, et al. Efficacy of Bazedoxifene in reducing new vertebral fracture risk in postmenopausal women with osteoporosis: results from a 3-year, randomized, placebo-, and active-controlled clinical trial. J Bone Miner Res. 2008:23:1923-34. doi:10.1359/jbmr.080710.

61. Palacios S, Silverman SL, de Villiers TJ, Levine AB, Goemaere S, Brown JP, Bazedoxifene Study Group, et al. A 7-year randomized, placebo-controlled trial assessing the long-term efficacy and safety of bazedoxifene in postmenopausal women with osteoporosis: effects on bone density and fracture. Menopause. 2015;22:806-13. doi:10.1097/GME.0000000000000419.

62. Pinkerton JV, Harvey JA, Lindsay R, Pan K, Chines AA, Mirkin S, et al. Effects of bazedoxifene/conjugated estrogens on the endometrium and bone: a randomized trial. J Clin Endocrinol Metab. 2014;99:E189-98. doi:10.1210/jc. 2013-1707.

63. Fisher B, Costantino JP, Wickerham DL, Cecchini RS, Cronin WM, Robidoux $A$, et al. Tamoxifen for the prevention of breast cancer: current status of the National Surgical Adjuvant Breast and Bowel Project P-1study. J Natl Cancer Inst. 2005;97:1652-62.

64. Maximov PY, Lee TM, Jordan VC. The discovery and development of selective estrogen receptor modulators (SERMs) for clinical practice. Curr Clin Pharmacol. 2013;8:135-55.

65. Zaman K, Thurliman B, Huober J, Schonenberger A, Pagani O, Luthi J, et al; Swiss Group for Clinical Cancer Research (SAKK). Bone mineral density in breast cancer patients treated with adjuvant Letrozole, tamoxifen, or sequences of Letrozole and tamoxifen in the BIG 1-98 study (SAKK21/07). Ann Oncol. 2012; 23: 1474-81. doi: 10.1093/annonc/mdr448.

66. McClung MR, Siris $E_{1}$ Cummings $S$, Bolognese $M$, Fttinger $M$, Moffett $A$, et al. Prevention of bone loss in postmenopausal women treated with Lasofoxifene compared with raloxifene. Menopause. 2006;13:377-86.

67. Cummings SR. Ensrud K, Delmas PD, LaCroix AZ, Vukicevic S, Reid DM, et al; PEARL Study Investigators. Lasofoxifene in postmenopausal women with osteoporosis. N Engl J Med. 2010;362:686-96. doi:10.1056/NEJMoa0808692

68. Komm BS, Chines AA. An update on selective estrogen receptor modulators for the prevention and treatment of osteoporosis. Maturitas. 2012;71:221-6.

69. Rosen HN, Rosen CJ, Schmader KE, Mulder JE. Calcitonin in the prevention and treatment of osteoporosis. Available at: www.uptodate.com. Accessed 4 Feb 2017.

70. FDA panel says to stop marketing salmon calcitonin for osteoporosis. Available at: http:// www.medscape.com/viewarticle/780323. Accessed 1 Jan 2017.

71. Iniguez-Ariza NM, Clarke BL. Bone biology, signaling pathways, and therapeutic targets for osteoporosis. Maturitas. 2015;82:245-55. doi:10.1016/j. maturitas.2015.07.003.

72. Neer RM, Arnaud CD, Zanchetta JR, Prince R, Gaich GA, Reginster JY, et al. Effect of parathyroid hormone (1-34) on fractures and bone mineral density in postmenopausal women with osteoporosis. N Engl J Med. 2001;344: 1434-41.

73. Rosen CJ, Drezner MK, Mulder JE. Parathyroid hormone therapy for osteoporosis. Available at: www.uptodate.com. Accessed 4 Feb 2017.

74. Cosman F. Abaloparatide: a new anabolic therapy on the horizon. Bonekey Rep. 2015;4:661. doi:10.1038/bonekey.2015.28.

75. Noorani M, Larijani B, Heshmat R. Comparison of the effectiveness of domestic commercial recombinant PTH (Forteo) in improving bone density in patients with osteoporosis. Iranian Journal of Diabetes and Metabolism. 2012;11:494-503. In Persian.

76. Chapurlat RD. Odanacatib: a review of its potential in the management of osteoporosis in postmenopausal women. Ther Adv Musculoskelet Dis. 2015;7:103-9. doi:10.1177/1759720x15580903.

77. Das S, Crockett JC. Osteoporosis- a current view of pharmacological prevention and treatment. Drugs Des Devel Ther. 2013;7:435-48.

78. Eastell R, Nagase S, Ohyama M, Small M, Sawyer J, Boonen S, et al. Safety and efficacy of the cathepsin $\mathrm{k}$ inhibitors ONO-5334 in postmenopausal osteoporosis: the OCEAN study. J Bone Miner Res. 2011;26:1303-12. doi:10. 1002/jbmr.341.

79. Melville NA. Odanacatib efficacy stays strong, side effects give pause. Medscape Medical News; September 19, 2014. Available at: http://www. medscape.com/viewarticle/832009. Accessed 4 Feb 2017.

80. Varenna M, Bertoldo F, Di Monaco M, Giusti A, Martini G, Rossini M. Italian Society of Osteoporosis, Mineral Metabolism and Skeletal Diseases (SIOMMMS); Italian Society of Rheumatology (SIR): Safety profile of drugs used in the treatment of osteoporosis: a systematical review of the literature. Reumatismo. 2013;65:143-66.

81. Kanis JA, Johansson H, Oden A, McCloskey EV. A meta-analysis of the effect of strontium ranelate on the risk of vertebral and non-vertebral fracture in postmenopausal osteoporosis and the interaction with FRAX ${ }^{\oplus}$. Osteoporosis Int. 2011;22:2347-55. doi:10.1007/s00198-010-1474-0.

82. O'Donnell S, Cranney A, Wells GA, Adachi JD, Reginster JY. Strontium ranelate for preventing and treating postmenopausal osteoporosis. Cochrane Database Syst Rev. 2006;3, CD005326. 
83. Recommendation to restrict the use of Protelos/Osseor (strontium ranelate). Available at: http://www.ema.europa.eu/ema/index.jsp\%3Fcurl=pages/ news_and_events/news/2013/04/news_detail_001774.jsp\%26mid= WC0b01ac058004d5c1). Accessed 30/Dec/2016

84. McClung MR, Grauer A, Boonen S, Bolognese MA, Brown JP, Diez-Perez A, et al. Romosozumab in postmenopausal women with low bone mineral density. N Engl J Med. 2014;370:412-20. doi:10.1056/NEJMoa1305224.

85. Recknor CP, Recker RR, Benson CT, Robins DA, Chiang AY, Alam J, et al. The effect of discontinuing treatment with blosozumab: follow-up results of a phase 2 randomized clinical trial in postmenopausal women with low bone mineral density. J Bone Miner Res. 2015;30:1717-25. doi:10.1002/jbmr.2489.

86. Banu J. Cause, consequences, and treatment of osteoporosis in men. Drugs Des Devel Ther. 2013;7:849-60. doi:10.2147/DDDT.S46101.

87. Sugiyama T, Torio T, Miyajima T, Kim YT, Oda H. Romosozumab and blosozumab: alternative drugs of mechanical strain-related stimulus toward a cure for osteoporosis. Front Endocrinol (Lausanne). 2015;6:54. doi:10.3389/ fendo.2015.00054.

88. MacNabb C, Patton D, Hayes JS. Sclerostin antibody therapy for the treatment of osteoporosis: clinical prospects and challenges. J Osteoporos. 2016;6217286. doi:10.1155/2016/6217286.

89. Salari P, Larijani B, Abdollahi M. Association of hyperhomocysteinemia with osteoporosis: a systematic review. Therapy. 2008;5:215-22.

90. Pacheco-Costa R, Han SW, Pochini AC, Reqinato RD. Gene therapy for osteoporosis. Acta Ortop Bras. 2011;19:52-7.

91. Baltzer AW, Whalen JD, Wooley P, Latterman C, Truchan LM, Robbins PD, et al. Gene therapy for osteoporosis: evaluation in a murine ovariectomy model. Gene Ther. 2001;8:1770-6.

92. Trifonova O, Knight RA, Lisitsa A, Melino G, Antonov AV. Exploration of individuality in drug metabolism by high-throughput metabolomics: the fast line for personalized medicine. Drug Discov Today. 2016;21:103-10. doi: 10.1016/j.drudis.2015.07.011.

93. Harsløf T, Langdahl BL. New horizons in osteoporosis therapies. Curr Opin Pharmacol. 2016;28:38-42. doi:10.1016/j.coph.2016.02.012.

94. Cosman F. Combination therapy for osteoporosis: are appraisal. Bonekey Rep. 2014:3:518. doi:10.1038/bonekey.2014.13.

95. Rosen HN, Drezner MK, Barbieri RL, Crowley.Jr WF, Mulder JE. Postmenopausal hormone therapy in the prevention and treatment of osteoporosis. Available at: www.uptodate.com. Accessed 4 Feb 2017.

96. Tseng LN, Sheu WH, Ho ES, Lan HH, Hu CC, Kao CH. Effects of alendronate combined with hormone replacement therapy on osteoporotic postmenopausal Chinese women. Metabolism. 2006;55:741-7.

97. Chen XX, Baum W, Dwyer D, Stock M, Schwabe K, Ke HZ, et al. Sclerostin inhibition reverses systemic, periarticular and local bone loss in arthritis. Ann Rheum Dis. 2013;72:1732-6. doi:10.1136/annrheumdis-2013-203345.

98. Mori S, Zhou H. Implementation of personalized medicine for fracture risk assessment in osteoporosis. Geriatr Gerontol Int. 2016;16 Suppl 1:57-65. doi: 10.1111/ggi.12721.

99. Katznelson L, Finkelstein JS, Schoenfeld DA, Rosenthal DI, Anderson EJ, Klibanski A. Increase in bone density and lean body mass during testosterone administration in men with acquired hypogonadism. J Clin Endocrinol Metab. 1996;81:4358-65.

100. Laurent M, Gielen E, Claessens F, Boonen S, Vanderschueren D. Osteoporosis in older men: recent advances in pathophysiology and treatment. Best Pract Res Clin Endocrinol Metab. 2013;27:527-39. doi:10.1016/j.beem.2013.04.010.

101. Finkelstein JS, Rosen CJ, Mulder JE. Treatment of osteoporosis in men. Available at: www.uptodate.com. Accessed 4 Feb 2017

102. Tracz MJ, Sideras K, Bolona ER, Haddad RM, Kennedy CC, Uraga MV, et al. Testosterone use in men and its effects on bone health. A systematic review and meta-analysis of randomized placebo-controlled trials. J Clin Endocrinol Metab. 2006;91:2011-6.

103. Watts NB, Adler RA, Bilezikian JP, Drake MT. Eastell R, Orwoll ES, et al; Endocrine society. Osteoporosis in men: an Endocrine Society clinical practice quideline. J Clin Endocrinol Metab. 2012;97:1802-22. doi:10.1210/jc.2011-3045.

104. Hasani-Ranjbar S, Larijani B, Abdollahi M. A systematic review of the potential herbal sources of future drugs effective in oxidant-related diseases. Inflamm Allergy Drug Targets. 2009;8:2-10.

105. Tabatabaei-Malazy O, Larijani B, Abdollahi M. A systematic review of in vitro studies conducted on effect of herbal products on secretion of insulin from Langerhans islets. J Pharm Pharm Sci. 2012;15:447-66.
106. Abdollahi M, Larijani $B$, Rahimi R, Salari P. Role of oxidative stress in osteoporosis. Therapy. 2005;2:787-96.

107. Salari Sharif $P$, Asalforoush M, Ameri F, Larijani B, Abdollahi M. The effect of n-3 fatty acids on bone biomarkers in Iranian postmenopausal osteoporotic women: a randomized clinical trial. Age (Dordr). 2010;32:179-86.

108. Depypere HT, Comhaire FH. Herbal preparations for the menopause: beyond isoflavones and black cohosh. Maturitas. 2014;77:191-4. doi:10.1016/ j.maturitas.2013.11.001.

109. Poluzzi E, Piccinni C, Raschi E, Rampa A, Recannatini M, DePonti F. Phytoestrogens in postmenopause: the state of the art from a chemical, pharmacological and regulatory perspective. Cur Med Chem. 2014;21:417-36.

110. Salari $P$, Rezaei A, Larijani $B$, Abdollahi M. A systematic review of the impact of n-3 fatty acids in bone health and osteoporosis. Med Sci Monit. 2008;14:RA37-44.

111. An J, Hao D, Zhang Q, Chen B, Zhang R, Wang Y, et al. Natural products for treatment of bone erosive diseases: the effects and mechanisms on inhibiting osteoclastogenesis and bone resorption. Int Immunopharmacol. 2016;36:118-31. doi:10.1016/j.intimp.2016.04.024

112. Liu J, Ho SC, Su YX, Chen WQ, Zhang CX, Chen YM. The effect of long-term intervention of soy isoflavones on bone mineral density in women: a metaanalysis of randomized controlled trials. Bone. 2009;44:948-53. doi:10.1016/j. bone.2008.12.020

113. Taku K, Melby MK, Takebayashi J, Mizuno S, Ishimi Y, Omori T, et al. Effect of soy isoflavone extract supplements on bone mineral density in menopausal women: meta-analysis of randomized controlled trials. Asia Pac J Clin Nutr. 2010:19:33-42.

114. Taku K, Melby MK, Kurzer MS, Mizuno S, Watanabe S, Ishimi Y. Effects of soy isoflavone supplements on bone turnover markers in menopausal women: systematic review and meta-analysis of randomized controlled trials. Bone. 2010:47:413-23. doi:10.1016/j.bone.2010.05.001.

115. Salari Sharif $P$, Nikfar $S$, Abdollahi M. Prevention of bone resorption by intake of phytoestrogens in postmenopausal women: a meta-analysis. Age (Dordr). 2011;33:421-31. doi:10.1007/s11357-010-9180-6.

116. Rayalam S, Della-Fera MA, Baile CA. Synergism between resveratrol and other phytochemicals: implications for obesity and osteoporosis. Mol Nutr Food Res. 2011;55:1177-85.

\section{Submit your next manuscript to BioMed Central and we will help you at every step:}

- We accept pre-submission inquiries

- Our selector tool helps you to find the most relevant journal

- We provide round the clock customer support

- Convenient online submission

- Thorough peer review

- Inclusion in PubMed and all major indexing services

- Maximum visibility for your research

Submit your manuscript at www.biomedcentral.com/submit
) Biomed Central 